\title{
Article \\ Selenium Biofortification of Lettuce Plants (Lactuca sativa L.) as Affected by Se Species, Se Rate, and a Biochar Co-Application in a Calcareous Soil
}

\author{
Ioannis Zafeiriou ${ }^{1}$, Dionisios Gasparatos ${ }^{1, * \mathbb{D}}$, Dafni Ioannou ${ }^{1}$, Dimitrios Kalderis ${ }^{2}$ and Ioannis Massas ${ }^{1, *}$ \\ 1 Laboratory of Soil Science and Agricultural Chemistry, Department of Natural Resources \\ Management \& Agricultural Engineering, School of Environment \& Agricultural Engineering, Agricultural \\ University of Athens, 11855 Athens, Greece; j.zafeiriou@gmail.com (I.Z.); dioannou@aua.gr (D.I.) \\ 2 Department of Electronic Engineering, School of Engineering, Hellenic Mediterranean University, \\ 73100 Chania, Greece; kalderis@hmu.gr \\ * Correspondence: gasparatos@aua.gr (D.G.); massas@aua.gr (I.M.)
}

Citation: Zafeiriou, I.; Gasparatos, D.; Ioannou, D.; Kalderis, D.; Massas, I. Selenium Biofortification of Lettuce Plants (Lactuca sativa L.) as Affected by Se Species, Se Rate, and a Biochar Co-Application in a Calcareous Soil. Agronomy 2022, 12, 131. https:// doi.org/10.3390/agronomy12010131 Academic Editor: Francesco Serio

Received: 24 November 2021 Accepted: 31 December 2021 Published: 5 January 2022

Publisher's Note: MDPI stays neutral with regard to jurisdictional claims in published maps and institutional affiliations.

Copyright: (C) 2022 by the authors. Licensee MDPI, Basel, Switzerland. This article is an open access article distributed under the terms and conditions of the Creative Commons Attribution (CC BY) license (https:// creativecommons.org/licenses/by/ $4.0 /)$.

\begin{abstract}
Selenium biofortification of lettuce plants was studied for two rates (5 and $10 \mathrm{mg} \mathrm{kg}^{-1}$ soil) of either selenate or selenite and for the effect of $5 \% w / w$ biochar addition. Lettuce seedlings were grown in pots containing $1 \mathrm{~kg}$ of a calcareous soil. Twelve weeks later, the plants were harvested and selenium (Se), phosphorus (P), and sulfur (S) concentrations were determined in heads and roots. Plant growth characteristics were measured and plant biometrics were assessed by NDVI, NDRE, and SPAD measurements. The highest Se concentration of $315.19 \mathrm{mg} \mathrm{kg}^{-1}$ D.W. and the highest amount of Se taken up by plants $(950.5 \mu \mathrm{g} / \mathrm{pot})$ were observed for the low selenate rate with biochar. The corresponding values for selenite treatments were an order of magnitude lower. Although in general, minor to severe toxicity symptoms occurred with selenium application in no biochar treatments (except selenite low rate), the addition of biochar secured plant growth and increased $S$ and $P$ concentrations in plants, regulating Se uptake by plants at high selenite rate and allowing maximum plant uptake at the low selenate rate. To propose an appropriate Se fertilization rate, the fate of excess selenates in the soil environment should be examined and experimentation under soil conditions is necessary.
\end{abstract}

Keywords: selenate; selenite; calcareous soil; biochar; lettuce

\section{Introduction}

Selenium (Se), at low concentrations, is an essential element for the normal growth and development of living organisms due to its crucial contribution to many biochemical reactions [1]. It regulates many functions in humans and animals such as antioxidant activity [2], proper functioning of the thyroid gland [3], and prevention of carcinogenesis [4]. There is also a positive effect of Se in plants as it enhances the tolerance to potentially toxic elements and pathogen stress and increases yield production [5-7], at proper concentrations. Because the optimum level of Se in living organisms is quite narrow in range [8,9], the deficiency of the element can rapidly be transformed into toxicity [10]. The optimal daily dose for humans is $55 \mu \mathrm{g}[11,12]$. Toxicity problems begin to appear when it exceeds $400 \mu \mathrm{g}$ [13].

Total Se concentration in soils worldwide ranges from $0.01-2.0 \mathrm{mg} \mathrm{kg}^{-1}$. Soils containing Se more than $2 \mathrm{mg} \mathrm{kg}^{-1}$ are designated as seleniferous [14,15] and have been reported in China, India, the USA, and Ireland. According to Gupta and Gupta [5], soils in Europe are rather poor in Se, especially in Germany, Finland, Scotland, the Balkan countries and Greece. Selenium can be found in soils as selenide $\left(\mathrm{Se}^{2-}\right)$, elemental selenium $\left(\mathrm{Se}^{0}\right)$, selenite $\left(\mathrm{SeO}_{3}{ }^{2-}\right)$, selenate $\left(\mathrm{SeO}_{4}{ }^{2-}\right)$, and organic selenium (SeCys and SeMet). Under common conditions, the most predominant species in soils are selenite $\left(\mathrm{SeO}_{3}{ }^{2-}\right)$ and selenate $\left(\mathrm{SeO}_{4}{ }^{2-}\right)[1,15]$. 
Humans get Se mainly through the food chain via crops. The amount of Se in crops depends on the available Se concentration in soil and the uptake ability of plants. Dinh et al. [16] proposed the term "bioavailability processes" to describe all the processes that control which Se species is available to enter plant molecular cells from the soil at a given time. These processes should be considered when agricultural products are fortified with Se, in the case of deficiency and when phytoremediation strategies are planned, in the case of toxicity. In addition to total Se concentration in soils, the speciation also influences the bioavailability of Se [1,15], therefore, the chemical behavior of Se and soil properties such as soil $\mathrm{pH} / \mathrm{Eh}$, concentration of clay, $\mathrm{Fe} / \mathrm{Mn} / \mathrm{Al}$ oxides, organic matter, and microbial activity, should be considered. The ability to predict the bioavailability of Se in the soil environment requires an understanding of sorption-desorption phenomena, oxidation-reduction reactions, complexation, and precipitation. Selenite $\left(\mathrm{SeO}_{3}{ }^{2-}\right)$ forms inner-sphere complexes with soil constituents and shows higher adsorption affinity than selenate $\left(\mathrm{SeO}_{4}{ }^{2-}\right)$ which tends to form outer-sphere complexes and so is more mobile than $\mathrm{SeO}_{3}{ }^{2-}$ in the soil environment $[1,17,18]$. Selenite binds onto humic acids through a metal bridge to form ternary complexes $[16,19]$. Under oxidizing conditions, selenate is the predominant species, whereas selenite is the predominant species under reducing conditions [20]. Selenite and selenate could both be adsorbed onto Fe oxides, and in the case of selenite stable inner-sphere complexes could be formed [16,17].

Plant uptake of Se is also specified by plant species [21] and since crops are the first link in the food chain, their ability to accumulate Se is crucial for human nutrition and health. Agronomic biofortification (fertilizers application) is a common practice to enrich Se concentration in crops that are produced in Se deficient soils $[18,22,23]$. In addition, it is considered a safe method as the chances of overdose consumed with plant foods are low [24] since Se occurs primarily in the protein fraction of fruits and vegetables [25]. Se concentration of plants is $1-2 \mathrm{mg} \mathrm{kg}^{-1}$ dry matter and rarely exceeds $10 \mathrm{mg} \mathrm{kg}^{-1}$ dry matter even in selenium-rich soils $[1,26]$.

Both, sodium selenate $\left(\mathrm{Na}_{2} \mathrm{SeO}_{4}\right)$ and sodium selenite $\left(\mathrm{Na}_{2} \mathrm{SeO}_{3}\right)$ are used as mineral Se fertilizers [27], and are preferred against organic fertilizers forms [16,28] because of the lower cost, the easier Se uptake by plants, and lower residual soil Se after application. Plants take up selenium as selenite and selenate which then is assimilated mainly into proteins and amino acids $[1,15,18]$. Selenite is transported by phosphate transporters, while selenate is transported through sulfate pathways [29]. Critical limits between selenium biofortification and toxicity are not established in the literature. It has been reported that selenite is more toxic than selenate for the same Se concentration [30], maybe because of the rapid transformation and assimilation of selenite into organic compounds as SeMet mainly in the roots [31,32]. Selenate is not rapidly transformed into organic forms in roots and redistributed within the plant [33]. The addition of Se in soil significantly increases Se concentration in spinach and lettuce plants, while negative effects to biomass and quality of leaves were not observed $[34,35]$. When toxicity occurred it resulted mainly in the reduction of plant growth.

Biochars are considered as environmentally friendly soil amendments that can control the bioavailability of nutrients [36] in soils and can positively affect plant growth and yield production [37]. Depending on the biomass originally used for the production of biochar, the addition of these carbonaceous materials in soils may improve water retention, nutrient availability, biological activity, and control alkalinity [37,38]. Encouraging results were also produced when biochars were tested for their ability to reduce the mobility of Potentially Toxic Elements (PTE's) in soil ecosystems [36,39].

Lettuce (Lactuca sativa L. var. longifolia) is a vegetable consumed greatly throughout the world $[40,41]$ and could be subjected to Se biofortification programs for human diet enrichment in Se [42].

As a result, after an extensive literature review, data regarding the effect of biochar addition in soils on Se mobility were found to be missing. This lack of information motivated the present study. Hence, lettuce plants (Lactuca sativa L.) were grown on a Se deficient 
calcareous soil that had received two rates ( 5 and $10 \mathrm{mg} \mathrm{Se} \mathrm{kg}^{-1}$ soil) of selenite $\left(\mathrm{SeO}_{3}{ }^{2-}\right.$ ) and selenate $\left(\mathrm{SeO}_{4}{ }^{2-}\right)$, combined with biochar application, aiming to (i) test the efficacy of the two Se species on biofortification of lettuce plants, and (ii) to evaluate the potential effects of co-addition of Se species and biochar on yield production, growth parameters and Se uptake by lettuce plants. Additionally, due to the anionic presence of sulfur (S), phosphorus (P), and selenium (Se) in the soil environment and the related behavior of these elements in plants, $\mathrm{S}$ and $\mathrm{P}$ concentration in plant tissues was also monitored and discussed in relation to Se uptake by plants and biochar application.

\section{Materials and Methods}

\subsection{Soil Selection and Characteristics}

A calcareous loam soil was collected from the agricultural area of Markopoulo, Eastern Attica, Greece, and transferred in sterile plastic bags to the laboratory, where it was air-dried, passed through a $2 \mathrm{~mm}$ sieve, and kept for further analysis. A complete set of soil analyses was performed, and the results are presented in Table 1. Soil pH and electrical conductivity $(\mathrm{EC})$ were measured in a 1:1 $(w / v)$ soil/water slurry [43]. Particle size distribution and organic carbon concentration were determined by the hydrometer method and by dichromate oxidation according to Walkley-Black's procedure, respectively [44,45]. Calcium carbonate equivalent was measured using a Bernard calcimeter [46], while active carbonate fraction was determined with the ammonium oxalate method proposed by Loeppert and Suarez [47]. Available phosphorus (Olsen-P) concentration was determined by extraction with sodium bicarbonate and measured at $882 \mathrm{~nm}$ with a Shimadzu UV-1700 Spectrophotometer, following color development achieved with Murphy-Riley addition [48]. Ammonium oxalate method was used to assess amorphous Fe, Mn, and Al oxides concentration, while free $\mathrm{Fe}, \mathrm{Mn}$, and $\mathrm{Al}$ oxides concentration were determined by the sodium-dithionate-bicarbonate (CDB) [49] and were quantified using a Varian SpectraA300 atomic absorption spectrophotometry. Total Selenium was extracted by aqua regia [50] and the very low selenium concentration in the extractant was analyzed using a Varian model VGA77 hydride generator.

Table 1. Soil properties.

\begin{tabular}{|c|c|c|c|c|c|c|c|c|c|c|c|c|c|c|}
\hline $\begin{array}{l}\text { Clay } \\
\mathrm{g} / \mathrm{kg}\end{array}$ & $\begin{array}{l}\text { Sand } \\
\mathrm{g} / \mathrm{kg}\end{array}$ & $\begin{array}{c}\text { Silt } \\
\text { g/kg }\end{array}$ & $\begin{array}{l}\text { pH } \\
1: 1\end{array}$ & $\begin{array}{c}\text { E.C. } \\
\mu \mathrm{S} / \mathrm{cm}\end{array}$ & $\begin{array}{l}\text { O.C. } \\
\text { g/kg }\end{array}$ & $\begin{array}{c}\mathrm{CaCO}_{3} \\
\mathrm{~g} / \mathrm{kg}\end{array}$ & $\begin{array}{c}\text { Act. } \\
\mathrm{CaCO}_{3} \\
\mathrm{~g} / \mathrm{kg}\end{array}$ & $\begin{array}{c}\mathrm{P} \\
\text { Olsen } \\
\mathrm{mg} / \mathrm{kg}\end{array}$ & $\begin{array}{l}\text { C.E.C. } \\
\mathrm{cmol}_{\mathrm{c}} / \mathrm{kg}\end{array}$ & $\begin{array}{c}\mathrm{Fe}_{\mathrm{d}} \\
\mathrm{g} / 100 \mathrm{~g}\end{array}$ & $\begin{array}{c}\mathrm{Fe}_{\mathrm{o}} \\
\mathrm{g} / 100 \mathrm{~g}\end{array}$ & $\underset{\mathrm{g} / 100 \mathrm{~g}}{\mathrm{Al}_{\mathrm{o}}}$ & $\underset{\mathrm{g} / 100 \mathrm{~g}}{\mathrm{Mn}_{\mathrm{d}}}$ & $\begin{array}{c}\text { Se } \\
\text { Total } \\
\mathrm{mg} / \mathrm{kg}\end{array}$ \\
\hline 180 & 400 & 420 & 7.4 & 575 & 13 & 184 & 47.5 & 15.4 & 20.4 & 1.16 & 0.14 & 0.04 & 0.05 & 0.175 \\
\hline
\end{tabular}

\subsection{Experimental Design}

A pot experiment was conducted under controlled greenhouse conditions, from midSeptember to late November 2020. Ten-day-old Lettuce seedlings (Lactuca Sativa L. var. longifolia) were transplanted into two sets of plastic pots (one plant per pot) filled with $1 \mathrm{~kg}$ soil that had passed through a $1 \mathrm{~cm}$ sieve. Fifty pots were used in total; pots were $17 \mathrm{~cm}$ high and $10 \mathrm{~cm}$ wide. One set of pots was without biochar application while $5 \%$ biochar was applied to the other set. Pots were watered every second to third day to maintain the soil water concentration between 60 and $65 \%$ of the water holding capacity. Along with transplantation, basic recommended fertilization N-P-K (15-15-15) equivalent to $2.5 \mathrm{~L}$ per hectare was applied with irrigation water, to ensure proper plant adaptation. The plants were allowed to grow for ten days to adapt well. Afterwards, the fifty healthiest plants were visually selected for the pot experiment, and crop vegetation activity and homogeneity at this stage were checked by NDVI (normalized difference vegetation index) and NDRE (normalized difference red edge) measurements.

Two identical two-factor experiments with five replicates for each treatment were conducted. The factors were Se rate (5 or $10 \mathrm{mg} \mathrm{Se} \mathrm{kg}^{-1}$ soil) and biochar (applied or not), while the form of selenium was the distinguishing factor of the two experiments as in one case Se was added in the form of selenite while in the other in the form of selenate. 
Thus, the following eight treatments emerged: (1) plants with the addition of $5 \mathrm{mg} \mathrm{kg}^{-1}$ selenite without biochar, (2) plants with the addition of $10 \mathrm{mg} \mathrm{kg}^{-1}$ selenite without biochar, (3) plants with the addition of $5 \mathrm{mg} \mathrm{kg}^{-1}$ selenite with biochar, and (4) plants with the addition of $10 \mathrm{mg} \mathrm{kg}^{-1}$ selenite with biochar, and repeat the same treatments with the application to be performed in the form of selenate, i.e., (5) plants with the addition of $5 \mathrm{mg} \mathrm{kg}^{-1}$ selenate without biochar, (6) plants with the addition of $10 \mathrm{mg} \mathrm{kg}^{-1}$ selenate without biochar, (7) plants with the addition of $5 \mathrm{mg} \mathrm{kg}^{-1}$ selenate with biochar and (8) plants with the addition of $10 \mathrm{mg} \mathrm{kg}^{-1}$ selenate with biochar. Plants grown without additional Se in any form, both in the presence and absence of biochar, were used as control plants. The young plants were exposed to different treatments by selenium application to soil, through irrigation water. Selenium was applied as sodium selenite $\left(\mathrm{Na}_{2} \mathrm{SeO}_{3}\right)$ or sodium selenate $\left(\mathrm{Na}_{2} \mathrm{SeO}_{4}\right)$, and the two rates of 5 and $10 \mathrm{mg} \mathrm{Se} \mathrm{kg}^{-1}$ soil were given in two doses during consecutive irrigations. The properties of biochar chosen for this experiment were determined in a previous study [51]. Briefly, biochar contains $185 \mathrm{~g} \mathrm{~kg}^{-1}$ organic carbon, $21.3 \mathrm{~g} \mathrm{~kg}^{-1}$ total nitrogen, $6.91 \mathrm{~g} \mathrm{~kg}^{-1} \mathrm{~S}$, and $60.5 \mathrm{~g} \mathrm{P} \mathrm{kg}^{-1}$. The pots were arranged in a complete randomized block design and rotated to change position at least once a week. Periodic monitoring was performed to assess visual symptoms (e.g., reduced growth, chlorophyll loss, etc.).

After 12 weeks, lettuce plants were harvested and divided into shoots (i.e., heads / above ground material) and roots. The roots were carefully washed with tap water to remove soil and other contaminants and rinsed with deionized water. The fresh weight of the shoots and roots as well as root length was measured. Due to the extremely low dry weight of the roots, the root material of all replications of the same treatment was mixed to yield a composite sample. NDVI, NDRE, and SPAD measurements were conducted at the end of the experiment.

Crop canopy reflectance was measured using the RapidSCAN CS-45 sensor by Holland Scientific, which is a completely self-contained active crop canopy sensor providing three measurement channels at the red, red edge, and near-infrared portions of the electromagnetic spectrum. The sensor's default vegetation indices (VI), normalized difference vegetation index (NDVI) (Equation (1)), and normalized difference red edge index (NDRE) (Equation (2)) were evaluated as promising tools for plant vigor and yield estimation [52].

$$
\begin{gathered}
\text { NDVI }=\frac{\text { NIR }- \text { RED }}{\text { NIR }+ \text { RED }} \\
\text { NDRE }=\frac{\text { NIR }- \text { REDGE }}{\text { NIR }+ \text { REDGE }}
\end{gathered}
$$

Reflectance data were collected right before the harvest. Even though the sensor has the ability to generate a height-independent spectral reflectance measurement, all the measurements were taken at a constant distance of approximately $20 \mathrm{~cm}$ from the top of the canopy. SPAD measurements were also recorded before harvesting by using a KONICA MINOLTA SPAD-502Plus portable chlorophyll-meter, which provides a non-destructive and rapid estimation of leaf chlorophyll concentration.

\subsection{Plant Tissue Analysis}

Plant samples were dried in an oven at $60^{\circ} \mathrm{C}$ until a constant weight was obtained and ground to $<0.5 \mathrm{~mm}$ in a stainless-steel mill (Retsch, ZM 1000). To extract Se, S, and P from plant tissues, samples of $1 \mathrm{~g}$ were digested on a hot plate $\left(80^{\circ} \mathrm{C}\right)$ by adding ultrapure concentrated $\mathrm{HNO}_{3}$ and drops of $30 \%(v / w) \mathrm{H}_{2} \mathrm{O}_{2}$ until the digestion solution became colorless or white, indicating the end of the digestion process [53]. Then, the digest was diluted to $25 \mathrm{~mL}$ with deionized water and analyzed for total Se, S, and P concentrations. Both Se and $\mathrm{S}$ concentrations in plants (shoots and roots) were determined by inductively coupled plasma mass spectroscopy (ICP-MS) (Thermo iCAPQc, Thermofisher SCIENTIFIC, Waltham, MA, USA). Phosphorus concentration was determined colorimetrically by molybdenum method using a Shimadzu UV-1700 Spectrophotometer. 


\subsection{Statistics}

The data of each factorial experiment were assessed by two-way ANOVA and comparisons between the treatment means were performed with Tukey's HSD test at $p<0.05$. Correlation analysis was also performed to identify significant correlations between the studied parameters. For the statistical analysis, STATISTICA software (Version 10) was used.

\section{Results}

\subsection{Plant Growth Characteristics}

\section{Selenite}

The D.W. of plants in selenite treatments ranged between 0.9 and $2.37 \mathrm{~g}$ (Table 2). The highest D.W. was observed for the treatments of $5 \mathrm{mg} \mathrm{kg}^{-1}$ soil and $10 \mathrm{mg} \mathrm{kg}^{-1}$ soil in the presence of biochar, while the lowest was with the addition of $10 \mathrm{mg} \mathrm{kg}^{-1}$ soil without biochar application. In all cases, biochar application increased D.W. of plants, while no significant differences in D.W. were found between the treatments where biochar was applied, regardless of the Se concentration. No significant differences were observed between the control plants and plants that received the low rate of selenium $\left(5 \mathrm{mg} \mathrm{kg}^{-1}\right.$ soil) in no biochar treatments. Moreover, the visual toxicity symptoms that were observed in plants exposed to the high selenite rate of $10 \mathrm{mg} \mathrm{kg}^{-1}$ soil without biochar reduced when biochar was added.

Table 2. Se, S, and P concentrations in lettuce plants and plant growth characteristics. Comparisons between treatments means performed by Tukey's HSD test and are valid within each Se species, i.e., selenite or selenate $(p<0.05)$. (Standard deviation in parenthesis, different lowercase letter indicates significant differences).

\begin{tabular}{|c|c|c|c|c|c|c|c|c|c|c|c|c|}
\hline & \multicolumn{5}{|c|}{ Selenite } & \multicolumn{7}{|c|}{ Selenate } \\
\hline & \multirow{2}{*}{\multicolumn{3}{|c|}{$\begin{array}{c}\begin{array}{c}\text { No } \\
\text { Biochar }\end{array} \\
\begin{array}{c}\text { Rate } \\
(\mathrm{mg} / \mathrm{kg})\end{array}\end{array}$}} & \multicolumn{3}{|c|}{ Biochar } & \multirow{2}{*}{\multicolumn{3}{|c|}{$\begin{array}{c}\begin{array}{c}\text { No } \\
\text { Biochar }\end{array} \\
\begin{array}{c}\text { Rate } \\
(\mathrm{mg} / \mathrm{kg})\end{array}\end{array}$}} & \multicolumn{3}{|c|}{ Biochar } \\
\hline & & & & & $\begin{array}{c}\text { Rate } \\
\text { (mg/kg) }\end{array}$ & & & & & & $\begin{array}{c}\text { Rate } \\
(\mathrm{mg} / \mathrm{kg})\end{array}$ & \\
\hline & 0 & 5 & 10 & 0 & 5 & 10 & 0 & 5 & 10 & 0 & 5 & 10 \\
\hline $\begin{array}{c}\text { Se } \\
(\mathrm{mg} / \mathrm{kg})\end{array}$ & $\begin{array}{l}0.14 \mathrm{a} \\
(0.01)\end{array}$ & $\begin{array}{c}10.11 \mathrm{~b} \\
(1.04)\end{array}$ & $\begin{array}{c}30.96 \mathrm{~d} \\
(3.69)\end{array}$ & $\begin{array}{l}0.24 \mathrm{a} \\
(0.04)\end{array}$ & $\begin{array}{c}10.19 \mathrm{~b} \\
(0.90)\end{array}$ & $\begin{array}{c}14.92 \mathrm{c} \\
(1.31)\end{array}$ & $\begin{array}{l}0.14 \mathrm{a} \\
(0.01)\end{array}$ & $\begin{array}{c}196.74 \text { c } \\
(14.53)\end{array}$ & $\begin{array}{c}111.17 \mathrm{~b} \\
(7.03)\end{array}$ & $\begin{array}{l}0.24 \mathrm{a} \\
(0.04)\end{array}$ & $\begin{array}{c}315.19 \mathrm{~d} \\
(12.99)\end{array}$ & $\begin{array}{c}207.19 \mathrm{c} \\
(8.41)\end{array}$ \\
\hline $\begin{array}{c}\mathrm{S} \\
(\mathrm{mg} / \mathrm{g})\end{array}$ & $\begin{array}{l}1.47 \mathrm{a} \\
(0.02)\end{array}$ & $\begin{array}{c}1.69 \mathrm{ab} \\
(0.13)\end{array}$ & $\begin{array}{c}1.53 \mathrm{ab} \\
(0.09)\end{array}$ & $\begin{array}{l}1.98 \mathrm{~b} \\
(0.09)\end{array}$ & $\begin{array}{l}4.39 c \\
(0.31)\end{array}$ & $\begin{array}{l}4.09 \mathrm{c} \\
(0.34)\end{array}$ & $\begin{array}{l}1.47 \mathrm{a} \\
(0.02)\end{array}$ & $\begin{array}{l}2.58 \mathrm{~b} \\
(0.32)\end{array}$ & $\begin{array}{l}1.21 \mathrm{a} \\
(0.04)\end{array}$ & $\begin{array}{c}1.98 \mathrm{ab} \\
(0.09)\end{array}$ & $\begin{array}{l}8.13 c \\
(0.81)\end{array}$ & $\begin{array}{l}2.48 \mathrm{~b} \\
(0.18)\end{array}$ \\
\hline$(\mathrm{mg} / \mathrm{g})$ & $\begin{array}{l}2.42 \mathrm{~b} \\
(0.15)\end{array}$ & $\begin{array}{c}2.33 \mathrm{ab} \\
(0.17)\end{array}$ & $\begin{array}{l}1.69 \mathrm{a} \\
(0.14)\end{array}$ & $\begin{array}{c}2.67 \mathrm{bc} \\
(0.07)\end{array}$ & $\begin{array}{l}3.47 \mathrm{c} \\
(0.53)\end{array}$ & $\begin{array}{l}3.30 \mathrm{c} \\
(0.36)\end{array}$ & $\begin{array}{l}2.42 \mathrm{~b} \\
(0.15)\end{array}$ & $\begin{array}{l}1.50 \mathrm{a} \\
(0.16)\end{array}$ & $\begin{array}{l}1.28 \mathrm{a} \\
(0.09)\end{array}$ & $\begin{array}{l}2.67 \mathrm{~b} \\
(0.07)\end{array}$ & $\begin{array}{l}3.60 \mathrm{c} \\
(0.61)\end{array}$ & $\begin{array}{l}1.51 b \\
(0.10)\end{array}$ \\
\hline $\begin{array}{l}\text { D.W. } \\
\text { (g) }\end{array}$ & $\begin{array}{l}1.38 \mathrm{~b} \\
(0.08)\end{array}$ & $\begin{array}{l}1.59 \mathrm{~b} \\
(0.23)\end{array}$ & $\begin{array}{l}0.90 \mathrm{a} \\
(0.09)\end{array}$ & $\begin{array}{l}2.01 \mathrm{c} \\
(0.10)\end{array}$ & $\begin{array}{l}2.37 \mathrm{c} \\
(0.23)\end{array}$ & $\begin{array}{l}2.25 \mathrm{c} \\
(0.11)\end{array}$ & $\begin{array}{c}1.38 \mathrm{ab} \\
(0.08)\end{array}$ & $\begin{array}{c}1.25 \mathrm{ab} \\
(0.27)\end{array}$ & $\begin{array}{c}1.12 \mathrm{ab} \\
(0.12)\end{array}$ & $\begin{array}{l}2.01 \mathrm{~b} \\
(0.10)\end{array}$ & $\begin{array}{l}3.01 \mathrm{c} \\
(0.79)\end{array}$ & $\begin{array}{l}0.95 \mathrm{a} \\
(0.12)\end{array}$ \\
\hline SPAD & $\begin{array}{c}24.36 \mathrm{~b} \\
(1.17)\end{array}$ & $\begin{array}{c}32.80 \mathrm{c} \\
(3.06)\end{array}$ & $\begin{array}{c}11.37 \mathrm{a} \\
(0.96)\end{array}$ & $\begin{array}{c}27.27 \mathrm{bc} \\
(3.51)\end{array}$ & $\begin{array}{c}23.60 \mathrm{~b} \\
(1.45)\end{array}$ & $\begin{array}{c}31.90 \mathrm{c} \\
(1.42)\end{array}$ & $\begin{array}{c}24.36 \mathrm{~b} \\
(1.17)\end{array}$ & $\begin{array}{c}20.04 \mathrm{ab} \\
(5.23)\end{array}$ & $\begin{array}{c}15.27 \mathrm{a} \\
(0.65)\end{array}$ & $\begin{array}{c}27.27 \mathrm{bc} \\
(3.51)\end{array}$ & $\begin{array}{c}32.88 \mathrm{c} \\
(2.72)\end{array}$ & $\begin{array}{c}15.70 \mathrm{a} \\
(1.83)\end{array}$ \\
\hline NDVI & $\begin{array}{c}0.916 \mathrm{~b} \\
(0.011)\end{array}$ & $\begin{array}{c}0.908 \mathrm{~b} \\
(0.008)\end{array}$ & $\begin{array}{l}0.683 \mathrm{a} \\
(0.013)\end{array}$ & $\begin{array}{c}0.917 \mathrm{~b} \\
(0.015)\end{array}$ & $\begin{array}{l}0.946 \mathrm{c} \\
(0.004)\end{array}$ & $\begin{array}{c}0.939 \mathrm{bc} \\
(0.028)\end{array}$ & $\begin{array}{l}0.916 \mathrm{c} \\
(0.011)\end{array}$ & $\begin{array}{l}0.820 \mathrm{~b} \\
(0.018)\end{array}$ & $\begin{array}{c}0.791 \mathrm{ab} \\
(0.078)\end{array}$ & $\begin{array}{l}0.917 \mathrm{c} \\
(0.015)\end{array}$ & $\begin{array}{l}0.928 \mathrm{c} \\
(0.015)\end{array}$ & $\begin{array}{l}0.725 \mathrm{a} \\
(0.026)\end{array}$ \\
\hline NDRE & $\begin{array}{c}0.343 \mathrm{ab} \\
(0.091)\end{array}$ & $\begin{array}{c}0.368 \mathrm{~b} \\
(0.048)\end{array}$ & $\begin{array}{l}0.230 \mathrm{a} \\
(0.027)\end{array}$ & $\begin{array}{c}0.333 \mathrm{ab} \\
(0.015)\end{array}$ & $\begin{array}{l}0.384 \mathrm{~b} \\
(0.029)\end{array}$ & $\begin{array}{c}0.360 \mathrm{ab} \\
(0.030)\end{array}$ & $\begin{array}{c}0.343 \mathrm{ab} \\
(0.091)\end{array}$ & $\begin{array}{l}0.253 \mathrm{a} \\
(0.044)\end{array}$ & $\begin{array}{c}0.330 \mathrm{ab} \\
(0.020)\end{array}$ & $\begin{array}{c}0.333 \mathrm{ab} \\
(0.015)\end{array}$ & $\begin{array}{l}0.370 \mathrm{~b} \\
(0.046)\end{array}$ & $\begin{array}{c}0.260 \mathrm{ab} \\
(0.029)\end{array}$ \\
\hline
\end{tabular}

SPAD values ranged between 11.37 and 32.80 (Table 2). These values correspond to the $10 \mathrm{mg}$ selenite $\mathrm{kg}^{-1}$ soil and the $5 \mathrm{mg}$ selenite $\mathrm{kg}^{-1}$ soil of no biochar treatments respectively. Biochar application did not significantly affect SPAD values for control plants. In no biochar treatments, SPAD values increased significantly in plants receiving low selenium rates compared to control plants and significantly decreased in plants receiving a high rate of selenium. In the biochar treatments, no significant differences in the SPAD values were observed. (Table 2).

NDVI values ranged between 0.683 and 0.946 corresponding to treatments of 10 and $5 \mathrm{mg} \mathrm{kg} \mathrm{soil}{ }^{-1}$ without and with biochar, respectively. In treatments without biochar, no significant differences were detected between the control plants and the plants that received 
the low selenium rate, while a significant decrease in NDVI values occurred for the plants that received the high selenium rate. In the biochar treatments, similar NDVI values were recorded for the control and the high selenite rate whereas a significantly higher value was measured low selenite rate. (Table 2). NDRE values followed a pattern similar to NDVI values.

Selenate

The D.W. of plants that received Se in the form of selenate ranged between 0.95 and $3.01 \mathrm{~g}$ (Table 2). The highest D.W. was observed for the treatments of $5 \mathrm{mg} \mathrm{kg}^{-1}$ soil with biochar, while the lowest with the addition of $10 \mathrm{mg} \mathrm{kg}^{-1}$ soil with biochar. At low-rate applications, the presence of biochar significantly increased the D.W. of plants, while at high-rate applications no significant differences for D.W. emerged. The severe visual toxicity symptoms that were observed in plants receiving the high selenate rate without biochar were only partially alleviated with the addition of biochar.

SPAD values ranged between 15.27 and 32.88 , corresponding to $10 \mathrm{mg}$ selenate $\mathrm{kg}^{-1}$ without biochar and $5 \mathrm{mg}$ selenate $\mathrm{kg}^{-1}$ soil with biochar, respectively. At a low rate of Se application, SPAD showed significantly higher values for treatments with biochar, as in the case of D.W., however, for high-rate applications, no significant differences appeared. Compared to control plants, the high Se rate led to significantly lower SPAD values irrespectively of biochar application.

The lowest NDVI value (0.725) was observed for the high selenate rate, while the highest (0.928), for the $5 \mathrm{mg}$ selenate $\mathrm{kg}^{-1}$ soil, both with biochar addition. In no biochar treatments, both low and high selenate rates resulted in significant decreases in NDVI values. In the presence of biochar, plants that received the high selenate rate presented significantly lower NDVI values compared either to control or to low selenate rate (Table 2).

\subsection{Selenium Concentration in Lettuce Plants}

Selenite

As was expected, the addition of selenite significantly increased Se concentration in the above-ground biomass of lettuce plants compared to controls. Selenium concentration ranged between 0.14 and $30.96 \mathrm{mg} \mathrm{kg}^{-1}$ D.W.; the lowest value recorded for the control without biochar and the highest for high selenite rate treatment without biochar (Table 2). Both in the presence and absence of biochar, the Se concentration in the above-ground biomass significantly increased from low to high-rate applications. Interestingly, while the presence of biochar had no effect on Se uptake when added at low-rate, the high-rate regulated the uptake of Se by reducing Se plant concentration thus resulting in the absence of toxicity and significantly higher dry weight (Table 2).

Selenate

Selenium concentration in plants treated with selenate ranged between 0.14 and $315.19 \mathrm{mg} \mathrm{kg}^{-1}$ D.W (Table 2). More specifically, the lowest value was recorded for the control plants without biochar and the highest for the plants that received the low selenate rate with biochar (Table 2). At both selenate rates, the presence of biochar significantly enhanced Se uptake. Moreover, irrespective of biochar application, Se concentration significantly decreased in above-ground biomass at high selenate rates compared to low selenate rate (Table 2).

\subsection{Sulfur Concentration in Lettuce Plants}

\section{Selenite}

The lowest $S$ concentration was observed in control plants without biochar (1.47 $\mathrm{g}$ $100 \mathrm{~g}^{-1}$ D.W. $)$ and the highest in plants receiving the low selenite rate with biochar $(4.39 \mathrm{~g}$ $100 \mathrm{~g}^{-1}$ D.W.) (Table 2). The presence of biochar significantly increased $\mathrm{S}$ concentration in the above-ground biomass, but no difference between selenite rates emerged (Table 2).

Selenate

The lowest $S$ concentration was observed in plants that received $10 \mathrm{mg}$ selenate $\mathrm{kg}^{-1}$

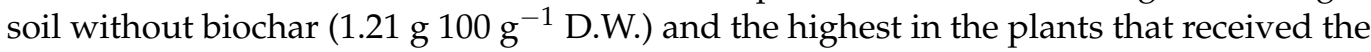




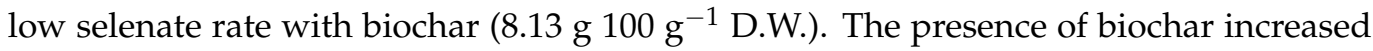
$\mathrm{S}$ concentration in above-ground plant tissues for all treatments although not always significantly, while significantly higher $\mathrm{S}$ concentrations in plants were recorded for low selenate rate treatments regardless of biochar addition (Table 2).

\subsection{Phosphorus Concentration in Lettuce Plants}

Selenite

Phosphorus concentration did not greatly differ between control plants with biochar and control plants without biochar, yet $\mathrm{P}$ concentrations were significantly higher for low and high-rate treatments with biochar in comparison to those without biochar (Table 2). For treatments with biochar, $\mathrm{P}$ concentration significantly increased in the $5 \mathrm{mg}$ selenite $\mathrm{kg}^{-1}$ soil treatment compared to control plants. In biochar-free treatments, the P concentration was significantly lower with the high selenite rate compared to the control (Table 2).

Selenate

Plants amended with biochar showed significantly higher P concentration in the low rate of selenate application, whereas high selenate rate significantly suppressed $\mathrm{P}$ concentration in plants compared to control (Table 2). In no biochar treatments, both selenate application rates resulted in a significant reduction of $\mathrm{P}$ in plant tissues compared to control plants.

\section{Discussion}

Regardless of species, Se addition to the soil led to a significant increase in Se concentration in plant tissues. However, when Se was added as selenate, its concentration in shoots was 10 times higher compared to selenite addition. These results are in full agreement with those of Ros et al. [54] and Zafeiriou et al. [55]. Selenate does not strongly adsorb on soil constituents since it mostly forms outer-sphere surface complexes [56]. This tendency makes it more mobile in the soil environment and available for plant uptake under favorable soil conditions (i.e., well-oxidized soils with above to close to neutral $\mathrm{pH}$ values), similar to those prevalent in the soil of the present work. On the other hand, selenite because it forms inner sphere complexes with Fe-Al oxides $[1,15,17]$, it becomes less mobile in the soil environment. According to Hayes et al. [56], selenite is strongly adsorbed on goethite, forming inner-sphere complexes, as well as on hematite as suggested by Duc et al. [57]. Furthermore, selenite adsorption in calcareous soils, such as our experimental soil, is affected by the presence of calcite which may reduce its mobility and availability $[58,59]$.

Lettuce (Lactuca sativa L.) is the most consumed vegetable in the human diet worldwide, providing mainly vitamins and micronutrients $[40,41]$. Increasing its nutritional value through agronomic techniques is a strategy adopted by an increasing number of producers in recent years [42]. Several studies have shown that the application of Se at rational concentrations, either as selenate or as selenite, to the rhizosphere of cultivated lettuce has led to a significant increase in fresh weight and improved biometric characteristics [5,18]. This is well supported by the study of Esringu et al. [60] who found that the application of $50-100 \mathrm{mg}$ selenite led to a $71-116 \%$ increase in yield compared to control plants. Moreover, Ramos et al. [42] reported that the application of a low selenate dose $(8 \mu \mathrm{mol} / \mathrm{L})$ in nutrient solution led to a $5.67 \%$ increase in shoot biomass of lettuce plants. On the other hand, the application of high doses of bioavailable Se leads to biomass reduction and toxicity symptoms both in lettuce and other plant species [5]. In the present study, the greatest effect on plant biomass was obtained by the application of $5 \mathrm{mg} \mathrm{kg}^{-1}$ selenate in combination with biochar, leading to a significant increase of $49.75 \%$ in the dry weight of above-ground plant tissues compared to the respective controls. It is worth noting that this biomass boost was accompanied by a significant increase in Se concentration in plant tissues (Table 2). According to the composition of the biochar, this material was rich in both $\mathrm{P}$ and $\mathrm{S}$ that were probably sufficiently available, promoting thus the growth of lettuce plants. Moreover, since biochar addition is expected to improve soil physical properties due to its low bulk 
density it might have also further contributed to the healthier plants' growth [61]. Similar results with improvement in the nutritional status of tomato plants in pot experiments after biochar application were obtained in the study by Akhtar et al. [62], with similar results seen in studies, e.g., in the review by Shaaban et al. [63] and references therein.

In no biochar treatments, however, high rates of selenite suppressed plants' growth (indicated by the $35 \%$ reduction in dry weight), in line with the results of HawrylakNowak [34].

In low selenite rate treatments, biochar application did not affect Se concentration in lettuce plants, whereas in high selenate treatments biochar significantly reduced Se concentration in plants. This retardation effect of biochar secured lettuce plants from toxicity that was observed for plants grown under a high selenite rate- no biochar as indicated by the significantly lower biomass and suppression of robustness indices values (Table 2). A mechanism that could possibly explain such a result is that increased selenite concentration in the soil environment mobilized additional phosphates and sulfates from biochar surfaces that in turn behaved antagonistically to selenites for plant uptake. The competing situation between the three oxyanions is well supported by findings included in the review of Zhou et al. [64]. The above interpretation is strongly supported by the fact that in the cases of biochar application the concentrations of $P$ and $S$ in shoots increased significantly compared to control, but also by the significant negative correlation between Se and $\mathrm{P}$ (Table 3).

Table 3. Significant correlations between selenium (Se), phosphorus (P), sulfur $(\mathrm{S})$ concentrations in lettuce plants and plant growth indices.

\begin{tabular}{|c|c|c|c|c|c|c|}
\hline \multicolumn{7}{|c|}{ Selenite $(n=14)$} \\
\hline & $\mathrm{Se}(\mathrm{mg} / \mathrm{kg})$ & $\mathrm{S}(\mathrm{mg} / \mathrm{g})$ & $P(\mathrm{mg} / \mathrm{g})$ & D.W. (g) & SPAD & NDVI \\
\hline \multicolumn{7}{|l|}{$\begin{array}{c}\mathrm{Se} \\
(\mathrm{mg} / \mathrm{kg})\end{array}$} \\
\hline \multicolumn{7}{|l|}{$\mathrm{S}(\mathrm{mg} / \mathrm{g})$} \\
\hline $\mathrm{P}(\mathrm{mg} / \mathrm{g})$ & $* /-$ & $* * * /+$ & & & & \\
\hline D.W. (g) & $* * * /-$ & $* * * /+$ & $* * * /+$ & & & \\
\hline SPAD & $* * * /-$ & $* /+$ & $* * * /+$ & $* * * /+$ & & \\
\hline NDVI & $* * * /-$ & $* * /+$ & $* * * /+$ & $* * * /+$ & $* * * /+$ & \\
\hline \multicolumn{7}{|c|}{ Selenate $(n=17)$} \\
\hline & Se (mg/kg) & $\mathrm{S}(\mathrm{mg} / \mathrm{g})$ & $P(\mathrm{mg} / \mathrm{g})$ & D.W. (g) & SPAD & NDVI \\
\hline \multicolumn{7}{|l|}{$\begin{array}{c}\mathrm{Se} \\
(\mathrm{mg} / \mathrm{kg})\end{array}$} \\
\hline $\mathrm{S}(\mathrm{mg} / \mathrm{g})$ & $* * * /+$ & & & & & \\
\hline $\mathrm{P}(\mathrm{mg} / \mathrm{g})$ & $* * * /+$ & $* * * /+$ & & & & \\
\hline D.W. (g) & $* * * /+$ & $* * * /+$ & $* * * /+$ & & & \\
\hline SPAD & $* * * /+$ & $* * * /+$ & $* * * /+$ & $* * * /+$ & & \\
\hline NDVI & $* * /+$ & $* * * /+$ & $* * * /+$ & $* * * /+$ & $* * * /+$ & \\
\hline
\end{tabular}

The low dose of selenate application when combined with biochar showed significantly higher Se concentration in plant tissues and at the same time significantly increased biomass, thus resulting in the highest overall uptake of Se by lettuce plants. This treatment also showed the highest values for $\mathrm{P}$ and $\mathrm{S}$ concentrations in plants, as well as for robustness indices. On the contrary, the application of the high dose of selenate, resulted in toxicity symptoms in plants, as they were reflected by both the values of the robustness indices and the decreased $\mathrm{P}$ and $\mathrm{S}$ concentrations in plants. Selenate uses $\mathrm{S}$ pathways to enter and move within the plant $[1,18]$, which in the present study is reflected by the strong positive correlation between Se and S concentrations in lettuce plants (Table 3).

The observed increasing trend of $\mathrm{P}$ and $\mathrm{S}$ concentrations in control plants that had received biochar can be attributed to the chemical composition of biochar. Specifically, 
the biochar used in this study had 6.15 and $0.69 \% \mathrm{P}$ and S, respectively, enriching the soil solution with these elements [51]. Both nutrients' concentrations in lettuce plants were significantly enhanced by the application of Se, with the exception of the dose of $10 \mathrm{mg}$ selenate $\mathrm{kg}^{-1}$ reaching values several times higher than the corresponding values of no biochar treatments. It seems that the high selenate concentration and mobility in the soil solution competitively reacted with $\mathrm{P}$ and $\mathrm{S}$ anions desorbing them from biochar surfaces and increased $\mathrm{P}$ and $\mathrm{S}$ availability for plant uptake. An opposite pattern was observed for the plants of the $10 \mathrm{mg}$ selenate $\mathrm{kg}^{-1}$ treatment in the presence of biochar which is probably due to the fact that lettuce plants in this treatment were in advanced stages of toxicity due to high selenate availability in soil, as was also indicated by the significantly lower values of NDVI/NDRE and SPAD measurements.

The NDVI and SPAD values reflected both the macroscopic image of the plants and the results of the laboratory analyses, as it is supported by the strong positive correlations between NDVI and SPAD values and the dry weight and the $S$ and the $P$ concentrations in lettuce plants (Table 3). Generally, NDVI and SPAD values were higher for healthy plants and showed a rising trend in cases of biometric characteristics improvement and $\mathrm{P}$ and $\mathrm{S}$ concentrations increased. On the contrary, lower NDVI and SPAD values were recorded in cases of plant stress and in the occurrence of toxicity. The above-mentioned importance of NDVI and SPAD measurements to depict conclusions regarding the nutritional status of plants as well as their complementary role in supporting laboratory analyses has been noted many times in the literature with several references summarized in the review by Bannari et al. [65]. NDRE values did not significantly correlate with the other variables of the experiment, in line with the results of a recently published work regarding selenium biofortification of rocket plants [55].

The translocation factors (TFs) of Se, S, and P were calculated as shoots/roots concentrations and are presented in Figure 1. Since one composite root sample was analyzed per treatment, the results of TFs should be considered as indicative, however, some important trends are highlighted. Regarding the Se application in the form of $\mathrm{SeO}_{3}{ }^{-2}$, TFs were in all cases $<1$, indicating that most of the amount taken up by the plants remained in the roots. These results are in agreement with the hydroponic experiment of Hawrylak-Nowak [34] in which it was observed that Se TFs in selenite treatments did not exceed 0.15. According to our results, the addition of biochar reduced the TF of selenite, from an average value of 0.49 to 0.22 , probably due to the suppressive effect of phosphates since both oxyanions utilize the same transporters in plants. However, this hypothesis is not clearly portrayed by the P TFs (Figure 1). On the other hand, a completely different picture was recorded for Se TFs in $\mathrm{SeO}_{4}{ }^{-2}$ treatments with values $>1$ for all treatments, indicating the higher amount of available Se translocated from roots to shoots when Se is added in this form. Similar results were reported by Ramos et al. [42] and by Hawrylak-Nowak [34]. More specifically, Ramos et al. [42] concluded that at low Se application rates $\left(2.4\right.$ and $\left.8 \mu \mathrm{mol} \mathrm{L}{ }^{-1}\right)$ about $70 \%$ of the Se taken up by plants as selenate ends up in the leaves, whereas for selenite uptake the corresponding percentage was about 50\%. Moreover, Hawrylak-Nowak [34] in a hydroponic lettuce cultivation experiment observed that the TF of selenate obtained an average value of 1.28 for all treatments. The application of biochar increased the $\mathrm{P}$ translocation factor in control plants, as a result of high $\mathrm{P}$ concentration in soil solution and better plant growth but did not have the same effect on S TFs. A significant positive correlation between Se and S TFs in selenate treatments strongly supports that selenate moved in the plant organs through $S$ transporters. 


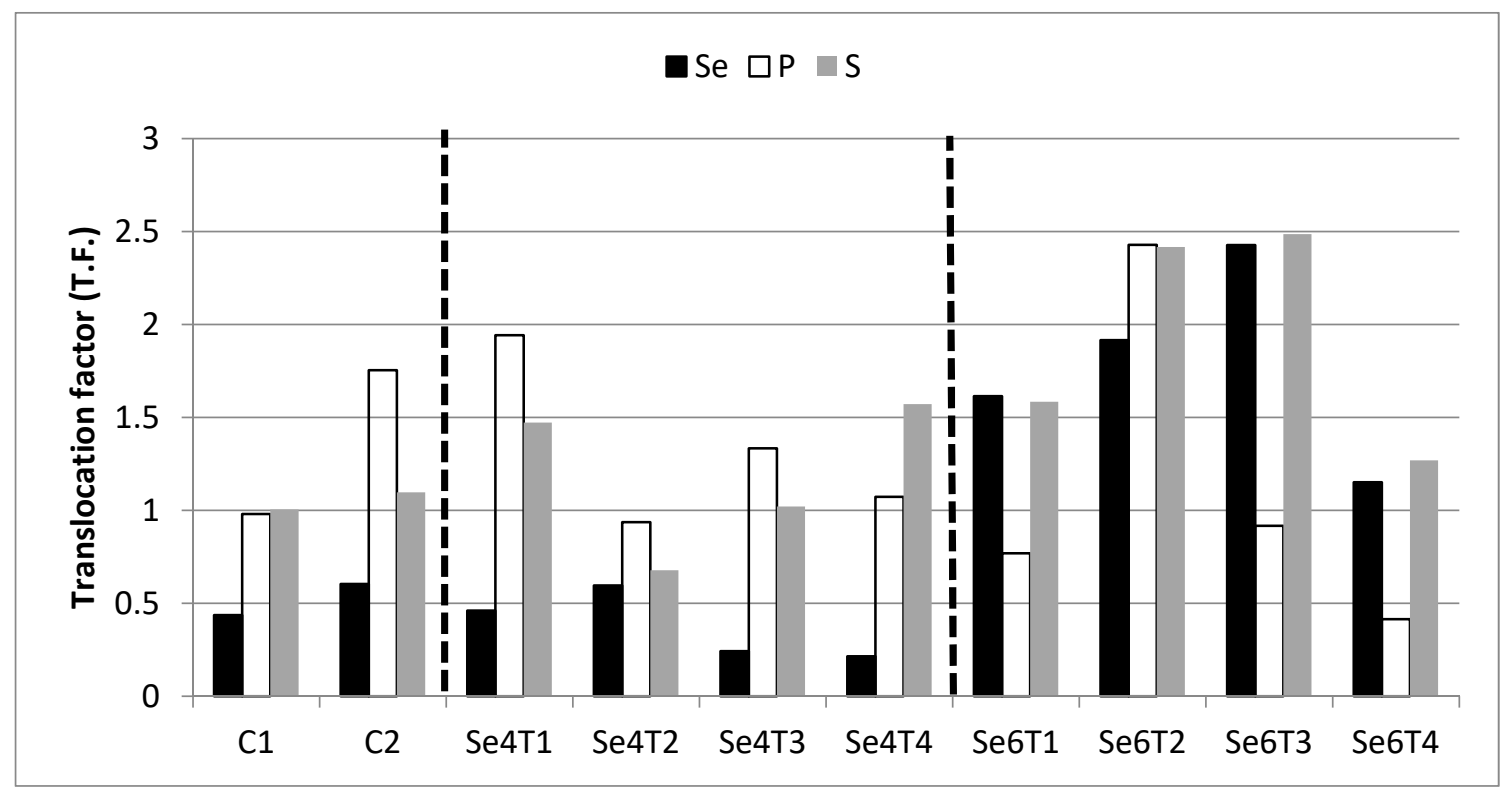

Figure 1. Selenium (Se), sulfur (S), and phosphorus (P) shoot/root translocation factors (T.F.) for controls and treatments. C1: Control without biochar, C2: Control with biochar, Se4: Selenite, Se6: Selenate, T1: $5 \mathrm{mg}$ Se/ $\mathrm{kg}$ soil without biochar, T2: $10 \mathrm{mg} \mathrm{Se} / \mathrm{kg}$ soil without biochar, T3: $5 \mathrm{mg}$ Se/ $\mathrm{kg}$ soil with biochar, T4: $10 \mathrm{mg} \mathrm{Se/kg} \mathrm{soil} \mathrm{with} \mathrm{biochar.}$

\section{Total Uptake of Selenium, Sulfur and Phosphorous}

To better evaluate the data of the present study, the total amount of Se, P, and S accumulated in lettuce plants was calculated according to the following formula: element concentration ( $\mathrm{mg} \mathrm{g}^{-1}$ D.W. plant) * (plant D.W.(g)/pot) and expressed as $\mathrm{mg} /$ pot. In our study, $\mathrm{mg} /$ pot equals $\mathrm{mg} / \mathrm{kg}$ soil as each pot contained $1 \mathrm{~kg}$ soil. The results are presented in Figure 2.

In both low and high-rate selenite application, the presence of biochar led to a significantly increased total Se uptake, giving an average value of $33.53 \mu \mathrm{g} /$ pot for the $10 \mathrm{mg}$ selenite $\mathrm{kg}^{-1}$ soil treatment, while the corresponding average value of the same selenite application rate without biochar was $27.87 \mu \mathrm{g} /$ pot. These results showed that for application rates up to 5 and $10 \mathrm{mg}$ selenite $\mathrm{kg}^{-1}$ soil, the co-addition of biochar leads to more robust plants with higher Se uptake supporting the biofortification of lettuce. The same pattern was recorded for the uptake of $S$ and $P$ which was affected by the presence of biochar showing significantly higher values for both rates of selenite. The high P and $\mathrm{S}$ concentration of biochar enhanced the uptake of these macro-elements by the lettuce plants, thus protecting plants against Se toxicity. In selenate treatments, the Se values recorded were found by orders of magnitude greater than those of selenite, reaching an average value of $950.5 \mu \mathrm{g} /$ pot for the $5 \mathrm{mg}$ selenate $\mathrm{kg}^{-1}$ soil application with biochar which is about 29 times higher than the maximum average total uptake value recorded for the selenite application. In contrast to selenite, the effect of biochar on Se uptake was significant only for the low selenate rate while no significant differences were observed for the control and the high rate. The same trend was also observed for the $\mathrm{S}$ and $\mathrm{P}$, as the application of biochar significantly affected their total uptake only in the case of the low selenate rate indicating a synergistic condition between the two macronutrients and selenates for plant uptake. 

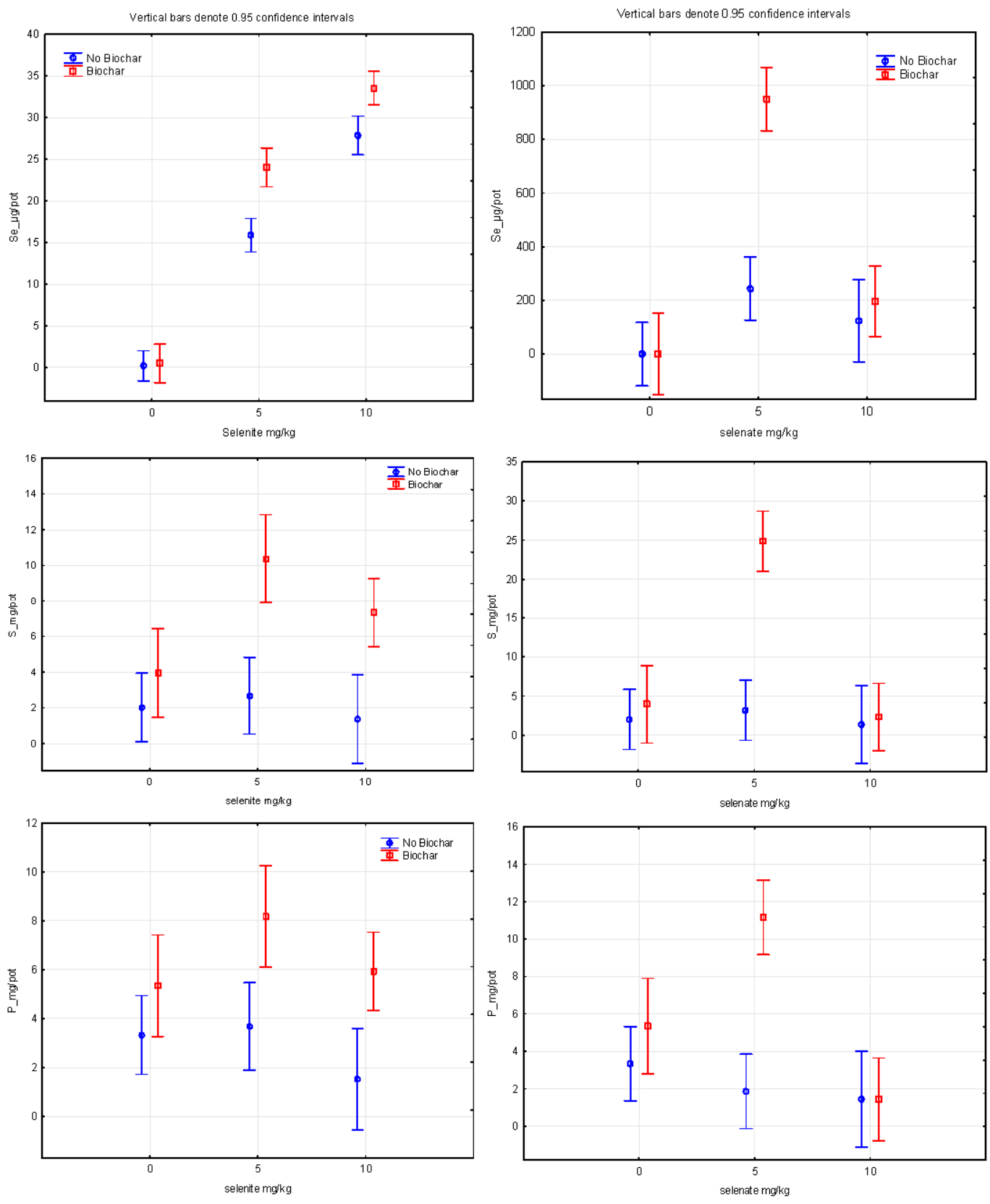

Figure 2. Selenium, sulfur, and phosphorus total uptake by lettuce plants.

\section{Conclusions}

The uptake of Se by lettuce plants grown in a calcareous loam soil was studied for different Se forms (sodium selenate and sodium selenite), rates (5 and $10 \mathrm{mg} \mathrm{kg}^{-1}$ D.W. soil), and for biochar co-application. The major findings of the study are:

- Biochar application reduced Se uptake with high selenite application rate and protected plants from Se toxicity leading also to the highest Se uptake $(\mu \mathrm{g} / \mathrm{pot})$. On the contrary, in the high selenate rate, biochar failed to secure plants from impaired growth probably due to the much higher mobility of selenate and availability in the alkaline soil environment compared to selenite.

- Visual and measurable toxic symptoms were observed in plants receiving the high selenate rate especially in the presence of biochar and the high selenite rate in the absence of biochar, as indicated by the decreased dry weight of the plants and the lower SPAD and NDVI values. 
- In selenate treatments, Se concentration in lettuce shoots was up to 10 times higher than in the selenite treatments, verifying the greater mobility of selenates in the alkaline soil environment, and the higher translocation of selenate from roots to shoots.

- Most of the Se in selenite treatments remained in roots, regardless of the presence or absence of biochar. The opposite was observed in selenate treatments, i.e., most of the Se transferred to shoots, also irrespectively of biochar application.

- In general, biochar application increased $\mathrm{S}$ and $\mathrm{P}$ concentration in plants when selenium was applied in any form.

- The significant positive correlations between Se, S, and P total uptake by plants (mg/pot) of selenate treatments suggest mutually beneficial interactions between the three nutrients, whereas the significant negative respective correlations in selenite treatments imply antagonistic behavior.

Although the results of the present study are encouraging regarding the possibility of increasing the nutritional value of lettuce through agronomic selenium application, and the beneficial role that the use of biochar may have in either increasing Se uptake or increasing plant nutrient status and protecting against toxicities, the high mobility of selenate in the soil environment and the narrow concentration range within which it may lead to toxicities are factors of concern. Since the valuable information obtained about toxicity due to the Se forms and rates depends on the biochar composition, these results set the basis for future studies on various soil types amended with biochars of different origin that will be important for practical agronomic and environmental applications.

Author Contributions: Conceptualization, I.Z., D.G., D.I. and I.M.; methodology, I.Z., D.G., D.I., D.K. and I.M.; validation, I.Z., D.G., D.I. and I.M.; formal analysis, I.Z., D.G., D.I. and I.M.; investigation, I.Z., D.G., D.I. and I.M.; resources, I.Z., D.G., D.K. and I.M.; data curation, I.Z., D.G., D.I. and I.M.; writing-original draft preparation, I.Z. and D.I.; writing—review and editing, I.Z., D.G., D.I. and I.M.; supervision, I.M.; funding acquisition, D.G. All authors have read and agreed to the published version of the manuscript.

Funding: This research received no external funding.

Data Availability Statement: The data are available upon request.

Conflicts of Interest: The authors declare no conflict of interest.

\section{References}

1. Winkel, L.H.E.; Vriens, B.; Jones, G.D.; Schneider, L.S.; Pilon-Smits, E.; Bañuelos, G.S. Selenium Cycling Across Soil-PlantAtmosphere Interfaces: A Critical Review. Nutrients 2015, 7, 4199-4239. [CrossRef] [PubMed]

2. Rayman, M.P. The argument for increasing selenium intake. Proc. Nutr. Soc. 2002, 61, 203-215. [CrossRef]

3. Holben, D.H.; Smith, A.M. The diverse role of selenium within selenoproteins: A review. J. Am. Diet. Assoc. 1999, 99, 836-843. [CrossRef]

4. Murdolo, G.; Bartolini, D.; Tortoioli, C.; Piroddi, M.; Torquato, P.; Galli, F. Selenium and Cancer Stem Cells. Adv. Cancer Res. 2017, 136, 235-257. [CrossRef] [PubMed]

5. Gupta, M.; Gupta, S. An Overview of Selenium Uptake, Metabolism, and Toxicity in Plants. Front. Plant Sci. 2017, 7, 2074. [CrossRef] [PubMed]

6. Schiavon, M.; Pilon-Smits, E.A.H. The fascinating facets of plant selenium accumulation—Biochemistry, physiology, evolution and ecology. New Phytol. 2017, 213, 1582-1596. [CrossRef]

7. Chauhan, R.; Awasthi, S.; Srivastava, S.; Dwivedi, S.; Pilon-Smits, E.A.; Dhankher, O.P.; Tripathi, R.D. Understanding selenium metabolism in plants and its role as a beneficial element. Crit. Rev. Environ. Sci. Technol. 2019, 49, 1937-1958. [CrossRef]

8. Rayman, M.P. Selenium and human health. Lancet 2012, 379, 1256-1268. [CrossRef]

9. Frączek, A.; Pasternak, K. Selenium in medicine and treatment. J. Elem. 2013, 18, 145-163. [CrossRef]

10. Sharma, S.; Kaur, N.; Kaur, S.; Nayyar, H. Selenium as a nutrient in biostimulation and biofortification of cereals. Indian J. Plant Physiol. 2016, 22, 1-15. [CrossRef]

11. World Health Organization (WHO). Global Health Risks: Mortality and Burden of Disease Attributable to Selected Major Risks; WHO: Geneva, Switzerland, 2009.

12. Malagoli, M.; Schiavon, M.; Dall'Acqua, S.; Pilon-Smits, E.A.H. Effects of selenium biofortification on crop nutritional quality. Front. Plant Sci. 2015, 6, 280. [CrossRef]

13. Kieliszek, M.; Błażejak, S. Selenium: Significance, and outlook for supplementation. Nutrition 2013, 29, 713-718. [CrossRef] 
14. Natasha Shahid, M.; Niazi, N.K.; Khalid, S.; Murtaza, B.; Bibi, I.; Rashid, M.I. A critical review of selenium biogeochemical behavior in soil-plant system with an inference to human health. Environ. Pollut. 2018, 234, 915-934. [CrossRef]

15. Schiavon, M.; Nardi, S.; dalla Vecchia, F.; Ertani, A. Selenium biofortification in the 21st century: Status and challenges for healthy human nutrition. Plant Soil 2020, 453, 245-270. [CrossRef]

16. Dinh, Q.T.; Cui, Z.; Huang, J.; Tran, T.A.T.; Wang, D.; Yang, W.; Zhou, F.; Wang, M.; Yu, D.; Liang, D. Selenium distribution in the Chinese environment and its relationship with human health: A review. Environ. Int. 2018, 112, 294-309. [CrossRef] [PubMed]

17. Zafeiriou, I.; Gasparatos, D.; Massas, I. Adsorption/Desorption Patterns of Selenium for Acid and Alkaline Soils of Xerothermic Environments. Environments 2020, 7, 72. [CrossRef]

18. Hossain, A.; Skalicky, M.; Brestic, M.; Maitra, S.; Sarkar, S.; Ahmad, Z.; Vemuri, H.; Garai, S.; Mondal, M.; Bhatt, R.; et al. Selenium Biofortification: Roles, Mechanisms, Responses and Prospects. Molecules 2021, 26, 881. [CrossRef] [PubMed]

19. Sharma, P.; Ofner, J.; Kappler, A. Formation of binary and ternary colloids anddissolved complexes of organic matter, Fe and As. Environ. Sci. Technol. 2010, 44, 4479-4485. [CrossRef]

20. Bassil, J.; Naveau, A.; Bueno, M.; Razack, M.; Kazpard, V. Leaching behavior of selenium from the karst infillings of the Hydrogeological Experimental Site of Poitiers. Chem. Geol. 2018, 483, 141-150. [CrossRef]

21. De Temmerman, L.; Waegeneers, N.; Thiry, C.; Du Laing, G.; Tack, F.; Ruttens, A. Selenium content of Belgian cultivated soils and its uptake by field crops and vegetables. Sci. Total Environ. 2014, 468-469, 77-82. [CrossRef] [PubMed]

22. Alfthan, G.; Eurola, M.; Ekholm, P.; Venäläinen, E.; Root, T.; Korkalainen, K.; Hartikainen, H.; Salminen, P.; Hietaniemi, V.; Aspila, P.; et al. Effects of nationwide addition of selenium to fertilizers on foods, and animal and human health in Finland: From deficiency to optimal selenium status of the population. J. Trace Elem. Med. Biol. 2015, 31, 142-147. [PubMed]

23. Lyons, G. Selenium in cereals: Improving the efficiency of agronomic biofortification in the UK. Plant Soil 2010, 332, 1-4. [CrossRef]

24. Terry, N.; Zayed, A.M.; de Souza, M.P.; Tarun, A.S. Selenium in higher plants. Annu. Rev. Plant Biol. 2000, 51, 401-432. [CrossRef] [PubMed]

25. dos Santos, M.; da Silva Júnior, F.; Muccillo-Baisch, A. Selenium content of Brazilian foods: A review of the literature values. J. Food Compos. Anal. 2017, 58, 10-15. [CrossRef]

26. Fordyce, F.M. Selenium deficiency and toxicity in the environment. In Essentials of Medical Geology; Selinus, O., Ed.; Elsevier: Amsterdam, The Netherlands, 2005; pp. 373-415.

27. Paciolla, C.C.; De Leonardis, S.; Dipierro, S. Effects of selenite and selenate on the antioxidant systems in Senecio scandens L. Plant Biosyst. 2011, 145, 253-259. [CrossRef]

28. Carvalho, K.M.; Gallardo-Williams, M.T.; Benson, R.F.; Martin, D.F. Effects of selenium supplementation on four agricultural crops. J. Agric. Food Chem. 2003, 51, 704-709. [CrossRef]

29. White, P.J.; Broadley, M.R.; Bowen, H.C.; Johnson, S.E. Selenium and its relationship with sulfur. In Sulfur in Plants An Ecological Perspective; Hawkesford, M.J., De Kok, L.J., Eds.; Springer: Dordrecht, The Netherlands, 2007; Volume 6. [CrossRef]

30. de Mello Prado, R.; Cruz, F.J.R.; da Cruz Ferreira, R.L. Selenium biofortification and the problem of its safety. In Superfood and Functional Food-An Overview of Their Processing and Utilization; IntechOpen: London, UK, 2017; pp. 229-238.

31. Zayed, A.; Lytle, C.; Terry, N. Accumulation and volatilization of different chemical species of selenium by plants. Planta 1998, 206, 284-292. [CrossRef]

32. Hu, T.; Li, H.; Li, J.; Zhao, G.; Wu, W.; Liu, L.; Wang, Q.; Guo, Y. Absorption and Bio-Transformation of Selenium Nanoparticles by Wheat Seedlings (Triticum aestivum L.). Front. Plant Sci. 2018, 9, 597. [CrossRef]

33. Li, H.F.; McGrath, S.P.; Zhao, F.J. Selenium uptake, translocation and speciation in wheat supplied with selenate or selenite. New Phytol. 2008, 178, 92-102. [CrossRef] [PubMed]

34. Hawrylak-Nowak, B. Comparative effects of selenite and selenate on growth and selenium accumulation in lettuce plants under hydroponic conditions. Plant. Growth Regul. 2013, 70, 149-157. [CrossRef]

35. Pezzarossa, B.; Petruzzelli, G.; Petacco, F.; Malorgio, F.; Ferri, T. Absorption of selenium by Lactuca sativa as affected by carboxymethylcellulose. Chemosphere 2007, 67, 322-329. [CrossRef] [PubMed]

36. Bilias, F.; Nikoli, T.; Kalderis, D.; Gasparatos, D. Towards a Soil Remediation Strategy Using Biochar: Effects on Soil Chemical Properties and Bioavailability of Potentially Toxic Elements. Toxics 2021, 9, 184. [CrossRef]

37. Jeffery, S.; Verheijen, F.; van der Velde, M.; Bastos, A. A quantitative review of the effects of biochar application to soils on crop productivity using meta-analysis. Agric. Ecosyst. Environ. 2011, 144, 175-187. [CrossRef]

38. El-Naggar, A.; Lee, S.; Rinklebe, J.; Farooq, M.; Song, H.; Sarmah, A.; Zimmerman, A.; Ahmad, M.; Shaheen, S.; Ok, Y. Biochar application to low fertility soils: A review of current status, and future prospects. Geoderma 2019, 337, 536-554. [CrossRef]

39. Kuppusamy, S.; Thavamani, P.; Megharaj, M.; Venkateswarlu, K.; Naidu, R. Agronomic and remedial benefits and risks of applying biochar to soil: Current knowledge and future research directions. Environ. Int. 2016, 87, 1-12. [CrossRef] [PubMed]

40. Hernandez, T.; Chocano, C.; Moreno, H.L.; Garcia, C. Use of compost as an alternative to conventional inorganic fertilizers in intensive lettuce (Lactuca sativa L.) crops-effect on soil and Plant Soil. Soil Tillage Res. 2016, 160, 14-22. [CrossRef]

41. Karapouloutidou, S.; Gasparatos, D. Effects of Biostimulant and Organic Amendment on Soil Properties and Nutrient Status of Lactuca Sativa in a Calcareous Saline-Sodic Soil. Agriculture 2019, 9, 164. [CrossRef]

42. Ramos, S.J.; Faquin, V.; Guilherme, L.R.G.; Castro, E.M.; Ávila, F.W.; Carvalho, G.S.; Bastos, C.E.A.; Oliveira, C. Selenium biofortification and antioxidant activity in lettuce plants fed with selenate and selenite. Plant Soil Environ. 2010, 56, 584-588. [CrossRef] 
43. Page, A.L. (Ed.) Methods of Soil Analysis, Part. 2, 2nd ed.; American Society of Agronomy: Madison, WI, USA, 1982.

44. Bouyoucos, G.J. A recalibration of the hydrometer method for making mechanical analysis of soils. Agron. J. 1951, 43, 434-438. [CrossRef]

45. Nelson, D.W.; Sommers, L.E. Total carbon, organic carbon and organic matter. In Methods of Soil Analysis, Part. 2, Chemical and Microbiological Properties; Page, A.L., Miller, R.H., Keeney, D.R., Eds.; ASA-SSSA: Madison, WI, USA, 1982.

46. NF ISO 10693. Détermination de la Teneuren Carbonate-Méthode Volumétrique; Qualité des Sols AFNOR: Paris, France, 1995; pp. 177-186.

47. Loeppert, R.H.; Suarez, D.L. Carbonate and gypsum. In Methods of Soil Analysis, Part. 3, Chemical Methods; Bigham, J.M., Bartels, J.M., Eds.; ASA-SSSA: Madison, WI, USA, 1982; pp. 437-474.

48. Olsen, S.R.; Cole, C.V.; Watanabe, F.S.; Dean, L.A. Estimation of Available Phosphorus in Soils by Extraction with Sodium Bicarbonate; US Department of Agriculture: Washington, DC, USA, 1954; Volume 939, pp. 1-19.

49. Gasparatos, D.; Haidouti, C.; Tarenidis, D. Characterization of iron oxides in Fe-rich concretions from an imperfectly-drained Greek soil: A study by selective-dissolution techniques and X-ray diffraction. Arch. Agron. Soil Sci. 2004, 50, 485-493. [CrossRef]

50. Hagarová, I.; Žemberyová, M.; Bajčan, D. Sequential and single step extraction procedures used for fractionation of selenium in soil samples. Chem. Pap. 2005, 59, 93-98.

51. Bachmann, H.; Bucheli, T.; Dieguez-Alonso, A.; Fabbri, D.; Knicker, H.; Schmidt, H.; Ulbricht, A.; Becker, R.; Buscaroli, A.; Buerge, D.; et al. Toward the Standardization of Biochar Analysis: The COST Action TD1107 Interlaboratory Comparison. J. Agric. Food Chem. 2016, 64, 513-527. [CrossRef]

52. Bonfil, D.J.; Gitelson, A.A. RapidScan and CropCircle radio-meters: Opportunities and limitation in assessing wheat bio-mass and nitrogen. In Proceedings of the 12th International Conference on Precision Agriculture, Sacramento, CA, USA, 20-23 July 2014. CD-ROM \#1369.

53. Jones, J.B.; Case, V.W. Sampling, handling and analysing plant tissue samples, In Soil Testing and Plant Analysis, 3rd ed.; Westerman, R.L., Ed.; Book Series No. 3; Soil Science Society of America: Madison, WI, USA, 1990; pp. 389-427.

54. Ros, G.; Rotterdam, A.; Bussink, D.; Bindraban, P. Selenium fertilization strategies for bio-fortification of food: An agro-ecosystem approach. Plant Soil 2016, 404, 99-112. [CrossRef]

55. Zafeiriou, I.; Gasparatos Ioannou, D.; Massas, I. Selenium uptake by rocket plants (Eruca sativa) grown in a calcareous soil as affected by Se species, Se rate and a seaweed extract-Based biostimulant application. Crop Pasture Sci. 2021; in press. Available online: https://www.publish.csiro.au/CP/justaccepted/CP21529 (accessed on 22 December 2021).

56. Hayes, K.F.; Roe, L.A.; Brown, G.E.; Hodgson, K.O.; Leckie, J.O.; Parks, G.A. In situ X-ray absorption study of surface complexes: Selenium oxyanions on $\alpha$-FeOOH. Science 1987, 238, 783-786. [CrossRef] [PubMed]

57. Duc, M.; Lefevre, G.; Fedoroff, M. Sorption of selenite ions on hematite. J. Colloid Interface Sci. 2006, 298, 556-563. [CrossRef] [PubMed]

58. Goldberg, S.; Glaubig, R.A. Anion sorption on a calcareous, montmorillonitic soil-selenium. Soil Sci. Soc. Am. J. 1988, 52, 954e958. [CrossRef]

59. Ramkissoon, C.; Degryse, F.; Young, S.; Bailey, E.; McLaughlin, M. Effect of soil properties on time-dependent fixation (ageing) of selenate. Geoderma 2021, 383, 114741. [CrossRef]

60. Esringu, A.; Ekinci, M.; Usta, S.; Turan, M.; Dursun, A.; Ercisli, S.; Yildirim, E. Selenium supplementation affects the growth, yield and selenium accumulation in lettuce (Lactuca sativa L.). C. R. Acad. Bulg. Sci. 2015, 68, 801.

61. Omondi, M.; Xia, X.; Nahayo, A.; Liu, X.; Korai, P.; Pan, G. Quantification of biochar effects on soil hydrological properties using meta-analysis of literature data. Geoderma 2016, 274, 28-34. [CrossRef]

62. Akhtar, S.; Li, G.; Andersen, M.; Liu, F. Biochar enhances yield and quality of tomato under reduced irrigation. Agric. Water Manag. 2014, 138, 37-44. [CrossRef]

63. Shaaban, M.; Van Zwieten, L.; Bashir, S.; Younas, A.; Núñez-Delgado, A.; Chhajro, M.; Kubar, K.; Ali, U.; Rana, M.; Mehmood, M.; et al. A concise review of biochar application to agricultural soils to improve soil conditions and fight pollution. J. Environ. Manag. 2018, 228, 429-440. [CrossRef] [PubMed]

64. Zhou, X.; Yang, J.; Kronzucker, H.; Shi, W. Selenium Biofortification and Interaction With Other Elements in Plants: A Review. Front. Plant Sci. 2020, 11. [CrossRef] [PubMed]

65. Bannari, A.; Morin, D.; Bonn, F.; Huete, A.R. A review of vegetation indices. Remote Sens. Rev. 1995, 13, 95-120. [CrossRef] 